\title{
A primary intervention concept for preventing work related stress in SMEs using in- house resources and competences
}

\author{
Gish, Liv; Ipsen, Christine
}

Publication date:

2013

Link back to DTU Orbit

Citation (APA):

Gish, L., \& Ipsen, C. (2013). A primary intervention concept for preventing work related stress in SMEs using inhouse resources and competences. Abstract from 10th International Conference on Occupational Stress and Health, Los Angeles, CA, United States.

\section{General rights}

Copyright and moral rights for the publications made accessible in the public portal are retained by the authors and/or other copyright owners and it is a condition of accessing publications that users recognise and abide by the legal requirements associated with these rights.

- Users may download and print one copy of any publication from the public portal for the purpose of private study or research.

- You may not further distribute the material or use it for any profit-making activity or commercial gain

- You may freely distribute the URL identifying the publication in the public portal

If you believe that this document breaches copyright please contact us providing details, and we will remove access to the work immediately and investigate your claim. 


\title{
A PRIMARY INTERVENTION CONCEPT FOR PREVENTING WORK RELATED STRESS IN SMES USING IN-HOUSE RESOURCES AND COMPETENCES
}

\author{
Liv Gish, PhD, DTU Management Engineering, Kgs. Lyngby, Denmark; Christine Ipsen, PhD
}

In Denmark highly specialized SMEs express an increasing need for change with respect to improve productivity and well-being and the associated unions support the need for new knowledge. Danish studies point at that it is especially high demands at work, poor planning, demanding projects, workload and project management which are the main problems. Although tools and methods are available as public resources and the companies acknowledge the need for change, they lack the resources and process competences required to initiate organizational changes and primary stress interventions. In larger companies such competences are often available in the HR department, but in SMEs the HR department does in most cases only consist of one person who is specialized in employment conditions and not in organizational change processes. Given these challenges our research question is thus: How can SMEs initiate and implement primary preventive interventions applying in-house resources and competences?

To answer this question a two-year research project has been initiated running from Sep. 2011 to Aug. 2013. The project focuses on developing a primary intervention concept for preventing work-related stress and support wellbeing and productivity in SMEs. A sketch of the concept was designed prior the project start based on the findings in the Danish research project "Knowledge work and Stress - between Enthusiasm and Strain" which aimed at preventing work related stress in large knowledge intensive companies. In order to refine and validate the concept in a SME context four Danish SMEs have agreed to implement the intervention concept over a period of six month. The companies are ranging from 40 to 170 employees and engage in manufacturing or IT services.

The aim of the poster is to present the primary intervention concept i.e. the different activities the companies are to conduct; the different roles managers and employees are assigned as well as the premises for the intervention. In the following we will briefly elaborate on these. In the intervention start-up phase the companies are informed about the intervention process and commitment and resources are ensured. Hereafter a project team in each company is formed consisting of one project manager and two facilitators and other relevant stakeholders. The project group is the primary driver of the process but in close collaboration with all the implicated employees and managers. The first collective activity is a FishBone workshop aiming at identifying the employees' experiences with enthusiasm and strain in their daily work. The outcome of the workshop is a prioritized list of working conditions which is to be changed in the following intervention. Hereafter two specific working conditions are chosen for implementation by the project team, but again in close dialogue with the implicated employees and managers. To mark the launch of the intervention process, a Kick-off event is held involving all employees and managers. In the following month the companies are to implement the changes. In order to monitor and adjust the process the facilitators interview their colleagues to get their point of view of how and why things are going well or not so well. The intervention finalizes with a chronicle workshop where employees and managers can evaluate the whole process and reflect on learning potentials for new interventions. The underlying premise for the intervention process is that it is the organizational changes and collective work which is in focus and not the individual. Furthermore both employees and managers on different organizational levels are involved in the whole process, and not only in the development or implementation of the intervention but also the ongoing monitoring and adjustment of the process.

The research team follows the process by observing the changes, conducting surveys, holding status meetings and interviewing stakeholders and the project team. The research team does not participate in corporate daily activities and the implementation of the changes.

The interventions in the four companies are still in their initial phase, so at the time of writing three out of the four companies have conducted the FishBone workshops and Kickoff events and have slowly but surely started to implement the changes. The preliminary results indicate that management support and allocation of resources is vital. Furthermore, the internal facilitators are important drivers of the change process, but they need support and they have requested easy-to-use tools. In order to provide them support the research team is investigating how the facilitators can get access to such support from the unions for example. Moreover, a network between the facilitators in the four companies is also initiated in order for them to support each other. Finally we have observed that the facilitators draw on non-work related competences such as personal coaching and creativity skills. 
Given that the interventions in the selected companies are conducted successfully we argue that a new organizational capability to address work-related stress in a collective and collaborative manner is developed in the participating companies. With a successfully conducted intervention we mean that the companies have been able to implement their own change proposals in a collective and collaborative process. By developing this organizational capability we expect that the companies would be able to repeat the process with new change proposals. And hopefully the intervention concept can be adopted by other SMEs without interference of the research team.

Corresponding Author - Liv Gish, PhD, DTU Management Engineering, Kgs. Lyngby, Denmark 